\title{
Effects of Dietary Amino Acid Balance on the Response of Dairy Cows to an Increase of Milking Frequency from Twice to Three Times Daily
}

\author{
J. -M. Yeo, C. H. Knight, and D. G. Chamberlain \\ Hannah Research Institute, Ayr, KA6 5HL, UK
}

\begin{abstract}
An experiment was conducted to examine how the response of dairy cows to a change from twice to three times-daily milking is affected by deficiencies in the dietary supplies of three amino acids, His, Met, and Lys. Six cows were used in a $6 \times 6$ Latin square with 14-d periods. The three dietary treatments were: grass silage and a cereal-based supplement containing feather meal as the sole protein supplement; the same silage-cereal diet supplying similar amounts of metabolizable and rumen-undegradable protein but with additional amounts of His, Met, and Lys in the form of fish meal; and the fish meal diet with additional metabolizable energy in the form of an additional $2 \mathrm{~kg} / \mathrm{d}$ of sugar beet pulp. Within each of these dietary treatments, the cows were milked twice and three times daily, making a total of six treatments. When cows were given the feather meal diet, even though dietary metabolizable energy was in considerable excess, a deficiency of specific amino acids prevented any increase in milk yield in response to increasing the frequency of milking from twice to three times daily. In contrast, when cows consumed a similar level of excess metabolizable energy and a similar level of rumen-undegradable protein for which the protein was of better amino acid balance (fish meal), the increased frequency of milking led to increased yield of milk and milk protein.
\end{abstract}

(Key words: dairy cow, amino acid, $3 \times$-daily milking, milk yield)

Abbreviation key: $2 \times=$ twice-daily milking, $3 \times=$ three times-daily milking, $\mathbf{M E}=$ metabolizable energy.

\section{INTRODUCTION}

It is well known that milking dairy cows three times rather than twice daily increases their milk yield. The response is rapid, occurring within hours and is main-

Received March 12, 2003.

Accepted May 19, 2003.

Corresponding author: D. G. Chamberlain; e-mail: chamberlaind@ hri.sari.ac.uk. tained for as long as frequent milking is continued (Wilde and Peaker, 1990). The size of response, however, varies widely from around 6 to $24 \%$ (DePeters et al., 1985; Dewhurst and Knight, 1994; Erdman and Varner, 1995; Klei et al., 1997). Some of the variability can be attributed to effects of genetics (Barnes et al., 1990), stage of lactation (Blatchford and Peaker, 1982), or cisternal size (Dewhurst and Knight, 1993), but the size of response appears not to be related to existing milk yield (Erdman and Varner, 1995). The effect of nutrition, however, has received little attention. It has been shown (Blatchford and Peaker, 1983) that hourly milking does not increase the milk yield of goats rationed well below their energy requirements for milk production but, beyond that, the effect of nutrition has not been systematically examined.

When the dietary supply of AA is deficient, increasing the frequency of milking will increase the secretion of milk protein only if more AA are made available, either by reducing their use for other purposes or through net mobilization of body protein. It is not known to what extent such changes in body metabolism of AA can be induced by the stimulus of increased milking frequency, which is regarded as local to the mammary gland itself (Wilde et al., 1987). This question is part of the larger one of to what extent changes in mammary metabolism can pull nutrients from the body against competing demands of other tissues.

We report results from an experiment that examined how the response of dairy cows to a change from twice $(\mathbf{2} \times)$ to three times $(3 \times)$ daily milking is affected by deficiencies in the dietary supplies of three AA, His, Met, and Lys. The AA deficiencies were obtained by feeding the cows a diet of grass silage and cereal, containing feather meal as the sole protein supplement, and which is known to be markedly deficient in His, Met, and Lys (Kim et al., 1999, 2000, 2001). Feather meal was replaced by fish meal in order to supplement the supplies of His, Met, and Lys.

\section{MATERIALS AND METHODS}

\section{Cows and Their Management}

The Home Office Inspectorate (United Kingdom) and the Ethical Review Committee of the Hannah Research 
Table 1. The chemical composition (\% of DM, unless stated otherwise) of the silage, the feather meal cube (FMC), the fish meal cube (FC), and sugar beet pulp (SBP) used in the experiment.

\begin{tabular}{lcccc}
\hline & Silage & FMC & FC & SBP \\
\hline DM, \% & 29.0 & 89.0 & 88.9 & 90.5 \\
OM & 89.7 & 91.0 & 88.8 & 86.1 \\
Total N & 2.93 & 4.42 & 4.23 & 1.61 \\
NPN, \% of total N & 75.2 & & & \\
Ammonia-N, \% of total N & 8.9 & & & \\
Water-soluble carbohydrate & 3.8 & 9.5 & 4.4 & 20.5 \\
Starch & 4.2 & 23.3 & 22.4 & 0.3 \\
pH & 9.3 & & & \\
Lactic acid $_{\text {DOMD }^{1}}$ & 68.7 & & & \\
\hline
\end{tabular}

${ }^{1}$ Digestible OM in the DM.

Institute approved all animal handling and experimental procedures. Six Friesian cows in their second lactation were used, and they were 9 to 14 wk into their lactation at the start of the experiment. Average BW of the cows was $534 \mathrm{~kg}(\mathrm{SD}=49.4)$. The animals were housed in a metabolism cubicle with water freely accessible. Silage was provided using an automatic feeder (RIC HF 2 PL, Insentec B. V., Marknesse, The Netherlands), and concentrates were given in two equal meals each day at milking times. The cows were milked twice daily at 0700 and $1500 \mathrm{~h}$ with an additional milking at $2200 \mathrm{~h}$ for a $3 \times$ milking treatment.

All animals were milked twice daily, and given ad libitum access to grass silage, $5 \mathrm{~kg} / \mathrm{d}$ of a feather meal cube (a pelleted mixture of $50 \%$ rolled barley, $25 \%$ feather meal, and $25 \%$ citrus pulp on a fresh weight basis) and $3 \mathrm{~kg} / \mathrm{d}$ of sugar beet pulp for $14 \mathrm{~d}$ before the start of the experiment. In experimental periods, the cows were given a basal diet consisting of a restricted amount of silage, which was $95 \%$ of ad libitum intake in the introductory period, and $3 \mathrm{~kg} / \mathrm{d}$ of sugar beet pulp. The silage was made from perennial ryegrass (Lolium perenne) cut at an early stage of growth and ensiled with the addition of an inoculum of Lactobacillus plantarum (Ecosyl; ICL pcl, Billingham, UK) at $3 \mathrm{~L} /$ tonne $\left(10^{6} \mathrm{cfu} /\right.$ $\mathrm{g}$ of silage) in a bunker silo of 70 -tonne capacity. The chemical compositions of the silage and the supplements are shown in Table 1.

\section{Experimental Treatments and Design}

The experiment was designed as a $6 \times 6$ Williams Latin square with 14-d periods. The dietary treatments were 1) the basal diet as described above plus $5 \mathrm{~kg} / \mathrm{d}$ of the feather meal cube; 2 ) the basal diet as described above plus $5 \mathrm{~kg} / \mathrm{d}$ of a supplement containing fish meal (fish meal cube, a pelleted mixture of 50\% rolled barley, $30 \%$ fish meal and $20 \%$ citrus pulp on a fresh weight basis); 3) fish meal treatment as described above plus
$2 \mathrm{~kg} / \mathrm{d}$ of sugar beet pulp (fish meal + metabolizable energy [ME]). The total diets for the three treatments contained 19.3, 19.1, and 18.5\% CP in the DM for feather meal, fish meal, and fish meal $+\mathrm{ME}$ respectively.

Under each dietary treatment, cows were milked $2 \times$ or $3 \times$ daily.

Food intake and milk yield were recorded daily. The composition of milk was determined on a representative, composite sample from the last four consecutive milkings in each period.

\section{Chemical Analysis}

Feeds and milk were analyzed as described previously (Kim et al., 1999). Digestible OM in the DM in silage was determined by the method of Morrison (1972).

\section{Statistical Analysis}

For statistical analysis, mean values for feed intake and milk yield were taken for the last $7 \mathrm{~d}$ of each experimental period. Results were analyzed by ANOVA using the directives of Genstat 5 using the model: Y (dependent variable $)=$ overall mean + cow + period + treatment + error.

All differences between treatment means were inspected by the least significant difference method at the $5 \%$ level.

One of the cows became lame during the fourth period, and her silage intake and milk production were depressed. Although she recovered well during the rest of the experiment, the data for this cow for that period were omitted from the statistical analysis.

\section{RESULTS}

Results for feed intake and milk production are given in Table 2. Because silage intake in the fish meal and the fish meal $+\mathrm{ME}$ treatments was restricted to the level of that in the feather meal treatment, silage intake between the treatments was similar. The additional 2 $\mathrm{kg} / \mathrm{d}$ of sugar beet pulp on the fish meal $+\mathrm{ME}$ treatment significantly increased total DMI relative to the other treatments. Sugar beet and cubes were completely consumed on all treatments.

Increasing the frequency of milking from $2 \times$ to $3 \times$ significantly increased milk yield for the fish meal and the fish meal $+\mathrm{ME}$ treatments but did not affect it for the feather meal treatment. Regardless of milking frequency, the yield of milk, milk protein, and lactose was significantly higher for the fish meal and the fish meal + ME treatments than for the feather meal treat- 
Table 2. Feed intake and milk production.

\begin{tabular}{|c|c|c|c|c|c|c|c|}
\hline & \multicolumn{6}{|c|}{ Treatments $^{1}$} & \multirow[b]{3}{*}{$\mathrm{SED}^{2}$} \\
\hline & \multicolumn{2}{|c|}{$\mathrm{FE}$} & \multicolumn{2}{|c|}{ FI } & \multicolumn{2}{|c|}{$\mathrm{FI}+\mathrm{ME}$} & \\
\hline & $2 \times$ & $3 \times$ & $2 \times$ & $3 \times$ & $2 \times$ & $3 \times$ & \\
\hline \multicolumn{8}{|l|}{ DMI, kg/d } \\
\hline Silage & 12.0 & 11.9 & 12.2 & 12.2 & 12.0 & 12.0 & 0.17 \\
\hline Total & $19.2^{\mathrm{a}}$ & $19.0^{\mathrm{a}}$ & $19.3^{\mathrm{a}}$ & $19.4^{\mathrm{a}}$ & $21.0^{\mathrm{b}}$ & $20.9^{b}$ & 0.17 \\
\hline Milk yield, $\mathrm{kg} / \mathrm{d}$ & $22.1^{\mathrm{a}}$ & $22.3^{\mathrm{a}}$ & $25.1^{\text {bc }}$ & $27.1^{\mathrm{d}}$ & $24.4^{\mathrm{b}}$ & $26.2^{\text {cd }}$ & 0.84 \\
\hline Protein, g/kg & $33.3^{\mathrm{a}}$ & $34.3^{\mathrm{a}}$ & $35.9^{\mathrm{b}}$ & $35.6^{\mathrm{b}}$ & $36.3^{\mathrm{b}}$ & $36.2^{\mathrm{b}}$ & 0.51 \\
\hline Protein, $\mathrm{g} / \mathrm{d}$ & $737^{\mathrm{a}}$ & $765^{\mathrm{a}}$ & $900^{\mathrm{bc}}$ & $961^{\mathrm{c}}$ & $883^{\mathrm{b}}$ & $945^{\mathrm{bc}}$ & 30.4 \\
\hline Fat, g/kg & $44.2 \mathrm{~b}$ & $42.5^{\mathrm{b}}$ & $35.8^{\mathrm{a}}$ & $38.3^{\mathrm{a}}$ & $37.8^{\mathrm{a}}$ & $38.2^{\mathrm{a}}$ & 1.56 \\
\hline Fat, $\mathrm{g} / \mathrm{d}$ & $973^{a b c}$ & $935^{\mathrm{ab}}$ & $898^{\mathrm{a}}$ & $1033^{c}$ & $911^{\mathrm{a}}$ & $997^{\mathrm{bc}}$ & 35.8 \\
\hline Lactose, $\mathrm{g} / \mathrm{kg}$ & $48.2^{\mathrm{b}}$ & $47.3^{\mathrm{a}}$ & $46.6^{\mathrm{a}}$ & $47.0^{\mathrm{a}}$ & $47.0^{\mathrm{a}}$ & $47.0^{\mathrm{a}}$ & 0.35 \\
\hline Lactose, g/d & $1067^{\mathrm{a}}$ & $1054^{\mathrm{a}}$ & $1171^{\mathrm{bc}}$ & $1272^{\mathrm{d}}$ & $1146^{\mathrm{b}}$ & $1229^{\text {cd }}$ & 37.2 \\
\hline
\end{tabular}

${ }_{\mathrm{a}, \mathrm{b}, \mathrm{c}, \mathrm{d}}$ Means in the same row with unlike superscripts differ significantly $(P<0.05)$ by $t$-test.

${ }^{1} \mathrm{FE}=$ Basal diet (see text) plus $5 \mathrm{~kg} / \mathrm{d}$ of the feather meal cube; $\mathrm{FI}=$ basal diet plus $5 \mathrm{~kg} / \mathrm{d}$ of a supplement containing fish meal (fish meal cube, a pelleted mixture of $50 \%$ rolled barley, $30 \%$ fish meal and $20 \%$ citrus pulp on a fresh weight basis; FI + ME = FI plus $2 \mathrm{~kg} / \mathrm{d}$ of sugar beet pulp.

${ }^{2} \mathrm{SED}$, standard error of differences.

ment. Within a milking frequency, however, there was no significant difference in the yield of milk and milk constituents between the fish meal and the fish meal $+\mathrm{ME}$ treatments. Within each dietary treatment, the concentrations of milk protein, fat, and lactose were not affected by the $3 \times$ milking, except that, with the feather meal diet, the $3 \times$ milking significantly reduced the concentration of lactose. In cows given the feather meal diet, the $3 \times$ milking did not affect the yields of milk protein, fat and lactose. With the fish meal diets, however, the $3 \times$ milking significantly increased the yields of milk fat and lactose, and tended to increase milk protein yield ( $P=0.062$ and $P=0.056$ for the fish meal and the fish meal + ME treatments, respectively). Regardless of milking frequency, the fish meal and the fish meal $+\mathrm{ME}$ treatments significantly increased the concentration of milk protein but decreased that of milk fat relative to the feather meal treatment.

\section{DISCUSSION}

To avoid differences in ME intake between treatments, which might cloud the interpretation of the results, we attempted to fix silage intake within the experiment. Silage intake for the fish meal diet was restricted to the level measured for the feather meal diet. Despite the attempt to control energy intake, it was envisaged that small differences in feed intake might still occur. Hence it was decided to include the additional ME treatment to measure the response to extra energy. The lack of response to that treatment confirmed that the small differences in feed intake could be ignored.

The lack of effect of increasing the frequency of milking from $2 \times$ to $3 \times$ on the feather meal treatment suggests that the deficient dietary supplies of His, Met, and
Lys blocked any increase in milk secretion; in contrast, when fish meal was included in the diet, a response to $3 \times$ milking was clearly evident. Although AA supply was not measured in the experiment, previous experiments with this diet clearly show that His, Met, and Lys are deficient and that milk yield responds markedly when these AA are infused intravenously (Kim et al., 1999; 2000; 2001).

Against the background of insufficient absorbable $\mathrm{AA}$, increasing the frequency of milking will increase the secretion of milk protein only if more amino acids are made available, either by sparing their use for purposes other than the synthesis of milk protein or through net mobilization of body protein. The lack of response with the feather meal treatment suggests that the stimulus of the increased frequency of milking was insufficient to induce such a change in AA metabolism.

One explanation proposed for the increased secretion of milk in response to increasing the frequency of milking is the removal of a local inhibitor of milk secretion from the gland. Milk secretion can be inhibited by a milk fraction derived from whey protein (Wilde et al., 1987) and also by a product of plasmin-induced breakdown of $\beta$-CN (Silanikove et al., 2000). How such factors might interact with nutrition is not known, but it is reasonable to expect that these feedback inhibitors of lactation would not operate when nutrient deficiency was setting secretion at a level well below the potential of the gland, a view supported by the demonstrated rapid and sizable increases in milk secretion in response to intravenous infusion of limiting AA (Kim et al., 1999, 2000). Indeed, it has been pointed out that, since the stimulatory response to increasing the frequency of milking is mediated locally, any systemic rate limitation by substrate supply acting directly on the 
mammary gland would prevent the response (Blatchford and Peaker, 1983). The present results go a stage further in showing that, against a background of insufficient dietary AA, the stimulus of $3 \times$ milking is not sufficient to induce a measurable change in the partition of AA use between body and udder.

\section{ACKNOWLEDGMENTS}

We thank I. Stewart and J. Davidson for skilled technical assistance and S. Robertson and his staff for care of the animals during the experiment.

\section{REFERENCES}

Barnes, M. A., R. E. Pearson, and A. J. Lukes-Wilson. 1990. Effects of milking frequency and selection for milk yield on productive efficiency of Holstein cows. J. Dairy Sci. 73:1603-1611.

Blatchford, D. R., and M. Peaker. 1982. Effects of frequent milking on milk secretion during lactation in the goat: Relation to factors which limit the rate of secretion. Q. J. Exp. Physiol. 67:303-310.

Blatchford, D. R., and M. Peaker. 1983. Effect of decreased feed intake on the response of milk secretion to frequent milking in goats. Q. J. Exp. Physiol. 68:315-318.

DePeters, E. J., N. E. Smith, and J. Acedo-Rico. 1985. Three or two times daily milking of older cows and first lactation cows for entire lactations. J. Dairy Sci. 68:123-132.

Dewhurst, R. J., and C. H. Knight. 1993. An investigation of the changes in sites of milk storage in the bovine udder over two lactation cycles. Anim. Prod. 57:379-384.
Dewhurst, R. J., and C. H. Knight. 1994. Relationship between milk storage characteristics and the short-term response of dairy cows to thrice-daily milking. Anim. Prod. 58:181-187.

Erdman, R. A., and M. Varner. 1995. Fixed yield responses to increased milking frequency. J. Dairy Sci. 78:1199-1203.

Kim, C.-H., J.-J. Choung, and D. G. Chamberlain. 1999. Determination of the first-limiting amino acid for milk production in dairy cows consuming a diet of grass silage and a cereal-based supplement containing feather meal. J. Sci. Food Agric. 79:1703-1708.

Kim, C.-H., J.-J. Choung, and D. G. Chamberlain. 2000. Variability in the ranking of the three most-limiting amino acids for milk protein production in dairy cows consuming grass silage and a cereal-based supplement containing feather meal. J. Sci. Food Agric. 80:1386-1392.

Kim, C.-H., J.-J. Choung, and D. G. Chamberlain. 2001. Estimates of the efficiency of transfer of L-histidine from blood to milk when it is the first-limiting amino acid for secretion of milk protein in the dairy cow. J. Sci. Food Agric. 81:1150-1155.

Klei, L. R., J. M. Lynch, D. M. Barbano, P. A. Oltenacu, A. J. Lednor, and D. K. Bandler. 1997. Influence of milking three times a day on milk quality. J. Dairy Sci. 80:427-436.

Morrison, I. M. 1972. A semi-micro method for the determination of lignin and its use in predicting the digestibility of forage crops. J. Sci. Food Agric. 23:455-463.

Silanikove, N., A. Shamay, D. Shinder, and A. Moran. 2000. Stress down regulates milk yield in cows by plasmin induced $\beta$-casein product that blocks $\mathrm{K}^{+}$channels on the apical membranes. Life Sci. 67:2201-2212.

Wilde, C. J., D. T. Calvert, A. Daly, and M. Peaker. 1987. The effect of goat milk fractions on synthesis of milk constituents by rabbit mammary explants and on milk yield in vivo: evidence for autocrine control of milk secretion. Biochem. J. 242: 285-288.

Wilde, C. J., and M. Peaker. 1990. Autocrine control in milk secretion. J. Agric. Sci. Camb. 114: 235-238. 